\title{
Settlement Growth Prediction Using Celullar Automata Model (Case study Lowokwaru District, Malang City)
}

\author{
$1^{\text {st }}$ Januar Dwi Harisandy ${ }^{1}, 2^{\text {nd }}$ Gunawan Prayitno ${ }^{1}, 3^{\text {rd }}$ Wahid Hasyim $^{1}$ \\ \{januardhs@gmail.com¹, gunawan_uin93@yahoo.com ${ }^{1}$, awhasyim@yahoo.com¹ \\ Brawijaya University, Faculty of Engineering, Malang, Indonesia ${ }^{1}$
}

\begin{abstract}
Land use change in urban areas is a necessity. Populations increase both naturally (birth and death) and unnatural (migration) encourages increasing demand for land. The city of Malang, one of the major cities of East Java province, is also facing the problem of land use change. The attraction of Malang as a major city and educational city in East Java could potentially drive change in land use, from agriculture to non agriculture, specifically to the use of settlements. From 2010 to 2015, the population grew by $7.7 \%$ and farmland decrease by $23 \%$. The Lowokwaru district was chosen as part of this study because several universities are located in this district, so the demand for land for settlement is higher than in the other districts. The research objective is to predict the growth potential for settlement in 2035 using cellular automata by Landusesim application. The analysis shows that the planned settlement demand for 2035 is $1,433.62$ hectares, while the available area is 682.15 hectares (sum of agricultural land and vacant land). On the basis of this forecast, if the policy is not implemented, Lowokwaru District of Malang City will not be able to provide land by 2035 . The analysis show that the available land can only satisfy $47.58 \%$ total land demand.
\end{abstract}

Keywords: land use change, cellular automata

\section{Introduction}

Land in urban and regional areas has a fixed and limited trend. While the demand for human activities, whether for settlement, trade and services, as well as other needs, continues to increase as the population grows. Present theories state that there is a value difference for lands in the city center and the suburbs. Land value is an assessment of land that is based on the ability of the land economically in relation to its productivity and economic strategy [1]. The value of land is the space value horizontally (distance decay principle from the center) based on Urban Growth Model [2]-[3].

The high value of land (expensive) in the city center is generally inaccessible to lowincome people, thus making the community shift to the suburbs. Thus the suburban area is an alternative to residential and other activities. Besides having an affordable price for middleincome residents, the suburbs is also an ideal place to live because they are far from the city crowd [4]-[5].

Changes in land use in the suburbs will lead to land conversion, primarily from agricultural land to other uses, more specifically settlements. This will continue to occur from 
time to time following human demand in supporting their life activities. Sprawling will continue to occur with increasing activities and human population in the region. Irawan and Friyatno [6] stated in the micro level, the process of changing agricultural land (land conversion) can be done by the farmers themselves or carried out by other parties.

Malang City as one of the big cities in Indonesia also faces this problem. The absence of an obligation to establish Sustainable Farming Land (LP2B) eases the change from agricultural land to non-agricultural land. Based on the data, the growth rate of Malang City population is an average of $3.7 \%$ per year [7]. The high rate of population growth also causes the demand for settlement land to be quite high. One of them is Lowokwaru District, where several universities are located. The existence of these universities encourages inward migration which in turn also increases demand for settlement areas. In Malang city, Prayitno and Sasongko [5] found that there is the gap between adequate shelter and affordable home in Malang City.

Lowokwaru District is one of the areas in Malang City that shows an increase in the population growth rate by $7.7 \%$ and the degradation of agricultural land in 2010 to 2015 by $23 \%$ or around 70.42 hectare [8]-[9]. The potential for increased settlement use and reduced agricultural land and green open space in Malang City is a problem due to the limited availability of vacant land, which may also increase Malang's temperature. According to Hasyim [10], the surface temperature of Malang City has increased due to the reduction of green open space.

Prediction of the potential increase in settlement land from agricultural land use is one of the efforts to anticipate the settlement increase that exceed the available land and can be a reference for decision-makers in managing the area. This research was conducted to provide preliminary information on the projected increase in settlement land demand over the next 15 to 20 years, allowing the government to take precautionary measures by developing appropriate policies or rules.

\section{Research Methodology}

Research on land use change modeling has become a major theme in the literature on urban and regional planning today. The current geospatial data is of high quality and combined with fast computer processing time, facilitate the management of land use.

Early land-use research, such as the classical use of land by Christaller (1933), Von Thunen (1826), Weber (1909) and Lösch (1940) were replaced by new models, econometric models, transport interaction model (LUTI) in Torrens [11], agent-based model [12] and cellular automata (CA) model, which interacts with the effects of parameters in use lands. This new model can develop better because of the availability of map data at different scales that exist in a city or region that builds sustainability and can be managed.

Cellular automata (CA) can be understood conceptually as a "cell-based" approach for dynamic modeling of the gravity process at the micro level [13]. Besides in land use modeling, it is also used to make a model for deforestation [14], forest fires [15], social phenomena [16] and other uses.

Cellular Automata (CA) is a powerful tool for dynamically modeling land-use changes and is a common tool for viewing spatial interactions. This has been implemented in land use models and can simulate different types of land use. This study adopted the concept of spatial evolution integrated in CA and applied to land use and land cover change. 
Research Location

The area that will be the object of research is Lowokwaru District, Malang City, East Java. Lowokwaru District is located in the western part of Malang City with an area of 2,089.51 Ha. Regionally, Lowokwaru District is influenced by the geographical conditions of Malang City which is located at coordinates 1120 34'09,48 "EL - 1120 41'34,93" EL and 70 54'52,22 "SL - 80 3'05, 11 "SL. Administratively, the Lowokwaru District consists of 12 SubDistricts shown in Figure 1.

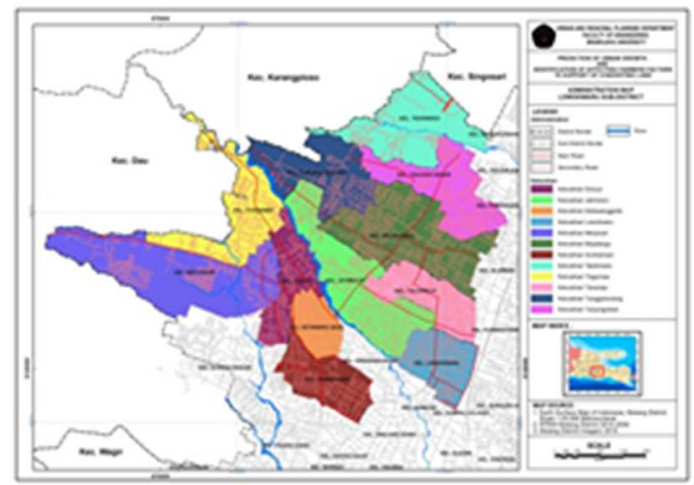

Figure 1. Administrative Map of Lowokwaru District

Overall, the Lowokwaru District area is a built-up area $(69 \%$ or $1578,176 \mathrm{Ha})$. Most of these are residential areas, covering an area of $1.234 .9 \mathrm{Ha}$ or $53 \%$, the rest is for services, education, and so on. This built-up area tends to develop in areas with relatively flat topographic conditions, namely in Lowokwaru, Mojolangu, Ketawang Gede, Sumbersari, Dinoyo. The rest are no building areas which are dry agricultural land (moor / fields) and wet agricultural land (rice fields) with an area of $579.78 \mathrm{Ha}$ or $25 \%$ in Merjosari Sub-district and Tlogomas Sub-district, while wet farmland (rice fields) are found in Merjosari Sub-district, Tlogomas Sub-district, Tunggul Wulung Sub-district, Jatimulyo Sub-district, Tunjung Sekar Sub-district and Tasikmadu Sub-district (Figure 2).

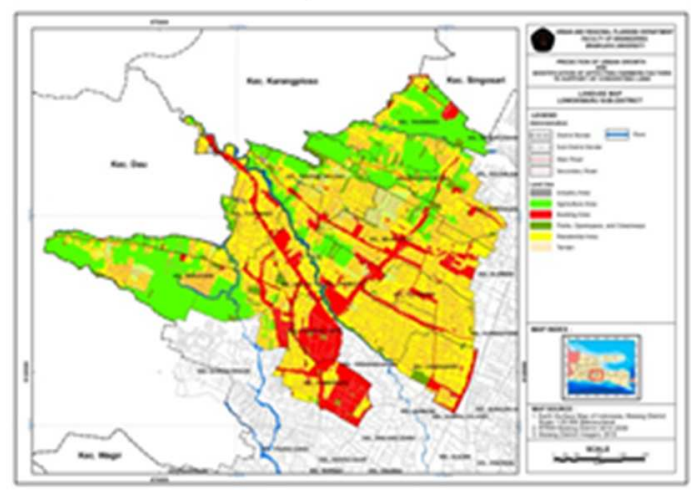

Figure 2. Land use in Kecamatan Lowokwaru 
Data Collection and Processing

The data used are secondary data, including the 2015 Lowokwaru District RDTR map, Malang City transportation network map, 2016 Lowokwaru District population, and the number of government programs that support land conversion.

Data processing in this study is done using spatial analysis with the help of Landusesim to determine the extent of land change and predictions of urban development (sprawling).

1. Cellular Automata Land Modeling Analysis

In modeling land development, researchers use cellular automata (CA) methods. CA is shown as a new branch of discipline (Wolfram, 2002). CA implementation has been carried out in various fields in the fields of transportation, human interaction, and urban development. The implementation of CA in modeling land use changes, in general, has been demonstrated [17-20].

In this study LanduseSim based on Cellular Automata was used as a spatial planning model software which describes the growth of settlement land in the research location.

2. Population Projection

The projection calculation for the population of Lowokwaru District is 20 years in the future using the exponential method (Equation 1).

$$
r=\left(\frac{P n-P o}{P o}\right) \%
$$

Where is Po as the base year population, $\mathrm{Pn}$ as the number of population in year $\mathrm{n}, \mathrm{r}$ as the ratio of population growth.

3. Projection of Home Demand

The occupancy rate can identify the home demand in the next 20 years. Equation 2 calculates House demands.

$$
R t p=\frac{P n}{I}
$$

The above area can obtain the formula to determine the allocation of the amount and area of housing land needed for the next 20 years.

$$
\begin{aligned}
& \text { Big House }=0.1 \times \text { the need total of houses } \times 120 \mathrm{~m}^{2} \\
& \text { Medium Houses }=0.3 \times \text { the need total of houses } \times 600 \mathrm{~m}^{2} \\
& \text { Small Houses }=0.6 \times \text { the need total of houses } \times 2000 \mathrm{~m}^{2}
\end{aligned}
$$

\section{Result}

\section{The extent of Agricultural Land in Lowokwaru District}

The area of agricultural land in Lowokwaru District is dominated by technical irrigated rice fields with the main crop being rice. Based on data from 2010, the figure was $311.62 \mathrm{Ha}$ with the amount of rice production being 3.918 tons, while in 2015 the area of rice fields was reduced to 241 hectares with a total production of 3,538.0 tons [8]. Table 1 shows data on agricultural land (rice fields and non-paddy fields) in Lowokwaru District from 2010 to 2015. 
Table 1. Area and number of agricultural land production in malang city

\begin{tabular}{|l|l|l|l|}
\hline \multirow{2}{*}{ ears } & \multicolumn{3}{|c|}{ Land (Ha) } \\
\cline { 2 - 4 } & $\begin{array}{l}\text { addy } \\
\text { Field }\end{array}$ & $\begin{array}{l}\text { ot } \\
\text { Paddy } \\
\text { ield }\end{array}$ & thers \\
\hline 010 & 11,62 & 02,44 & \\
\hline 011 & 95,0 & $.964,35$ &, 649 \\
\hline 012 & 46,0 & $.799,0$ & 14,29 \\
\hline 013 & 41,0 & 6,66 & $.932,34$ \\
\hline 014 & 41,0 & 6,0 &, 0 \\
\hline 015 & 41,0 & 7,0 & $.932,0$ \\
\hline
\end{tabular}

\begin{tabular}{|c|c|c|c|c|}
\hline \multirow{2}{*}{ ears } & \multicolumn{4}{|c|}{ Production (Ton) } \\
\cline { 2 - 5 } & addy & orn & assava & $\begin{array}{c}\text { weet } \\
\text { potato }\end{array}$ \\
\hline 010 & $.918,0$ & 3,0 &, 00 & 9,0 \\
\hline 011 & $.933,0$ & 01,0 & $.134,0$ & 8,0 \\
\hline 012 & $.943,0$ & 37,0 & 28,0 & \\
\hline 013 & $.872,0$ & 82,0 & $.606,0$ & \\
\hline 014 & $.754,0$ & 91,0 & $.420,0$ & \\
\hline 015 & $.538,0$ &, 00 &, 00 & \\
\hline
\end{tabular}

\section{Population Projection}

To find out the demand for settlements in Malang City, population projections were analyzed. The projection of population growth shows an increase every year from 2016-2035. The average population growth rate of Lowokwaru District is $4.7 \%$ per year so that the projection in the year 2035 has a population of 561,599 people (Table 2)

Table 2. Projection of the people 2015-2035

\begin{tabular}{|l|l|l|l|l|l|}
\hline District & 016 & 017 & 018 & 019 & 020 \\
\hline
\end{tabular}




\begin{tabular}{|l|c|c|c|c|c|}
\hline District & $\mathbf{0 1 6}$ & $\mathbf{0 1 7}$ & $\mathbf{0 1 8}$ & $\mathbf{0 1 9}$ & $\mathbf{0 2 0}$ \\
\hline Klojen & 55494 & 58747 & 62069 & 65460 & 68922 \\
\hline Blimbing & 71375 & 71184 & 70993 & 70802 & 70612 \\
\hline Lowokwaru & 34163 & 45196 & 56749 & 68846 & 81513 \\
\hline Sukun & 90468 & 92311 & 94172 & 96051 & 97949 \\
\hline Kedungkandang & 77712 & 78366 & 79023 & 79682 & 80343 \\
\hline
\end{tabular}

\begin{tabular}{|l|c|c|c|c|c|}
\hline District & $\mathbf{0 2 1}$ & $\mathbf{0 2 2}$ & $\mathbf{0 2 3}$ & $\mathbf{0 2 4}$ & $\mathbf{0 2 5}$ \\
\hline Klojen & 72456 & 76064 & 79748 & 83509 & 87349 \\
\hline Blimbing & 70422 & 70232 & 70042 & 69853 & 69664 \\
\hline Lowokwaru & 94777 & 08666 & 23210 & 38438 & 54384 \\
\hline Sukun & 99865 & 01799 & 03752 & 05724 & 07715 \\
\hline Kedungkandang & 81007 & 81674 & 82342 & 83014 & 83687 \\
\hline
\end{tabular}

\begin{tabular}{|c|c|c|c|c|c|}
\hline District & $\begin{array}{c}02 \\
6 \\
\end{array}$ & $\mathbf{0 2 7}$ & 028 & 029 & 030 \\
\hline Klojen & $\begin{array}{c}91 \\
26 \\
9\end{array}$ & 95271 & 99357 & 03528 & 07786 \\
\hline Blimbing & $\begin{array}{c}69 \\
47 \\
5 \\
\end{array}$ & 69286 & 69097 & 68909 & 68720 \\
\hline Lowokwaru & $\begin{array}{c}71 \\
08 \\
2 \\
\end{array}$ & 88566 & 06874 & 26045 & 46119 \\
\hline Sukun & $\begin{array}{c}09 \\
72 \\
5 \\
\end{array}$ & 11755 & 13804 & 15873 & 17963 \\
\hline Kedungkandang & $\begin{array}{c}84 \\
36 \\
4\end{array}$ & 85042 & 85724 & 86407 & 87094 \\
\hline
\end{tabular}

\begin{tabular}{|l|l|l|l|l|l|}
\hline District & 031 & 032 & 033 & 034 & 035 \\
\hline
\end{tabular}




\begin{tabular}{|l|c|c|c|c|c|}
\hline District & $\mathbf{0 3 1}$ & $\mathbf{0 3 2}$ & $\mathbf{0 3 3}$ & $\mathbf{0 3 4}$ & $\mathbf{0 3 5}$ \\
\hline Klojen & 12134 & 16572 & 21104 & 25730 & 30453 \\
\hline Blimbing & 68532 & 68345 & 68157 & 67970 & 67783 \\
\hline Lowokwaru & 67138 & 89149 & 12196 & 36329 & 61599 \\
\hline Sukun & 20072 & 22202 & 24352 & 26524 & 28716 \\
\hline Kedungkandang & 87782 & 88474 & 89168 & 89864 & 90563 \\
\hline
\end{tabular}

Projection of Home Demand for 2015 to 2035

Based on the results of population projections of the data, it can be seen (Table 3) that the area of land needed for the overall development of housing in Malang years is $4.124 \mathrm{Ha}$ in 2035

Table 3. Projected area of land needed housing in Malang

\begin{tabular}{|l|c|c|c|c|c|}
\hline District & $\mathbf{0 3 1}$ & $\mathbf{0 3 2}$ & $\mathbf{0 3 3}$ & $\mathbf{0 3 4}$ & $\mathbf{0 3 5}$ \\
\hline Klojen & $\begin{array}{c}1213 \\
4\end{array}$ & 16572 & 21104 & 25730 & 30453 \\
\hline Blimbing & $\begin{array}{c}6853 \\
2\end{array}$ & 68345 & 68157 & 67970 & 67783 \\
\hline Lowokwaru & $\begin{array}{c}6713 \\
8\end{array}$ & 89149 & 12196 & 36329 & 61599 \\
\hline Sukun & $\begin{array}{c}2007 \\
2\end{array}$ & 22202 & 24352 & 26524 & 28716 \\
\hline Kdkandang & $\begin{array}{c}8778 \\
2\end{array}$ & 88474 & 89168 & 89864 & 90563 \\
\hline
\end{tabular}

\section{Backlog of 2035}

The House Backlog is one of the indicators used by the Government as stated in the Strategic Plan (Renstra) [21] and the Medium Term Development Plan (RPJMN) related to the housing sector to measure the number of housing needs in Indonesia. The home backlog from the perspective of occupancy is calculated by referring to the concept of ideal calculation: 1 family occupies 1 house. Equation 5 is used to calculate the home backlog from the perspective of occupancy. Residential backlogs in Lowokwaru District can be seen in Table 4

$$
\text { Backlog }=\sum \text { Number of Family }-\sum \text { Housing }
$$


Table 4. Projected number of housing by type of house in 2035

\begin{tabular}{|l|c|cc|c|}
\hline \multirow{2}{*}{ District } & \multicolumn{4}{|c|}{$\begin{array}{c}\text { Houses Type 2035 } \\
\text { (Unit) }\end{array}$} \\
\cline { 2 - 5 } & ig & \multicolumn{1}{|c|}{ Medium } & mall \\
\hline Klojen &, 414 & 6,242 & 2,485 \\
\hline Blimbing &, 208 & 2,625 & 1 & 5,251 \\
\hline Lowokwaru & 2,228 & 6,686 & 3 & 3,372 \\
\hline Sukun &, 555 & 6,665 & 1 & 3,330 \\
\hline Kedungkandang &, 711 & 4,135 & 8,270 \\
\hline Total & 2,116 & 6,353 & 92,708 \\
\hline
\end{tabular}

The housing backlog is calculated for Lowokwaru District, where the calculation shows there is the need for small, medium and large houses. Based on calculations, the backlog of 66,381 , consisting of small houses $(39,828)$, medium houses $(11,948)$ and large houses $(1,194)$. The comparison for medium, small and large houses is 1: 3 : 6 . This means that the provision of 1 large house must be accompanied by 3 medium houses and 6 small houses.

Table 5. The demand of land area for lowokwaru district settlement in 2035

\begin{tabular}{lllll}
\hline \multirow{2}{*}{ Years } & \multirow{2}{*}{ Backlog } & \multicolumn{3}{c}{ Houses Type (Unit) } \\
\cline { 3 - 5 } & & Big & Medium & Small \\
\hline $\mathbf{2 0 3 5}$ & $\mathbf{6 6 , 3 8 1}$ & $\mathbf{3 9 , 8 2 8}$ & $\mathbf{1 1 , 9 4 8}$ & $\mathbf{1 , 1 9 4}$ \\
\hline
\end{tabular}

Projection of Lowokwaru District Settlement Land Area in 2035

The area of settlement land in 2035 is obtained from the number of projections based on the proportion of housing 1: 3: 6 for large, medium and small houses. Furthermore, the projection based on the type is multiplied by the lot area per each type of house that is specified in the Development Plan and Development of Housing and Settlement Region (RP3KP) Malang (22]. Prediction of the need for settlement area of Lowokwaru District in 2035 can be seen in Table 6

Table 6. The demand of land area for lowokwaru district settlement in 2035

\begin{tabular}{|c|c|c|c|c|}
\hline \multicolumn{3}{|c|}{ Land Area } & \multirow{2}{*}{$\begin{array}{c}\text { Land Area } \\
\text { Needed } \\
\text { (Hectares) }\end{array}$} & \multirow{2}{*}{$\begin{array}{c}\text { Land Area } \\
\text { Needed } \\
\text { (metersquare) }\end{array}$} \\
\hline ig & edium & mall & & \\
\hline & & & & 14 \\
\hline 77.94 & 16.88 & 38.80 & , 433.62 & ,336,160.00 \\
\hline
\end{tabular}




\section{Euclidean Distance Analysis}

This analysis is a measurement of horizontal distance that is measured based on raster data, which calculates the distance of a center of pixels past the center of the other pixels towards the object / phenomenon specified. Based on the driving factors in the development of settlement land in poor cities, 3 factors were determined, namely the existing settlement land (Figure 3.a), the primary road (Figure 3.b), and the secondary road (Figure 3.c). 

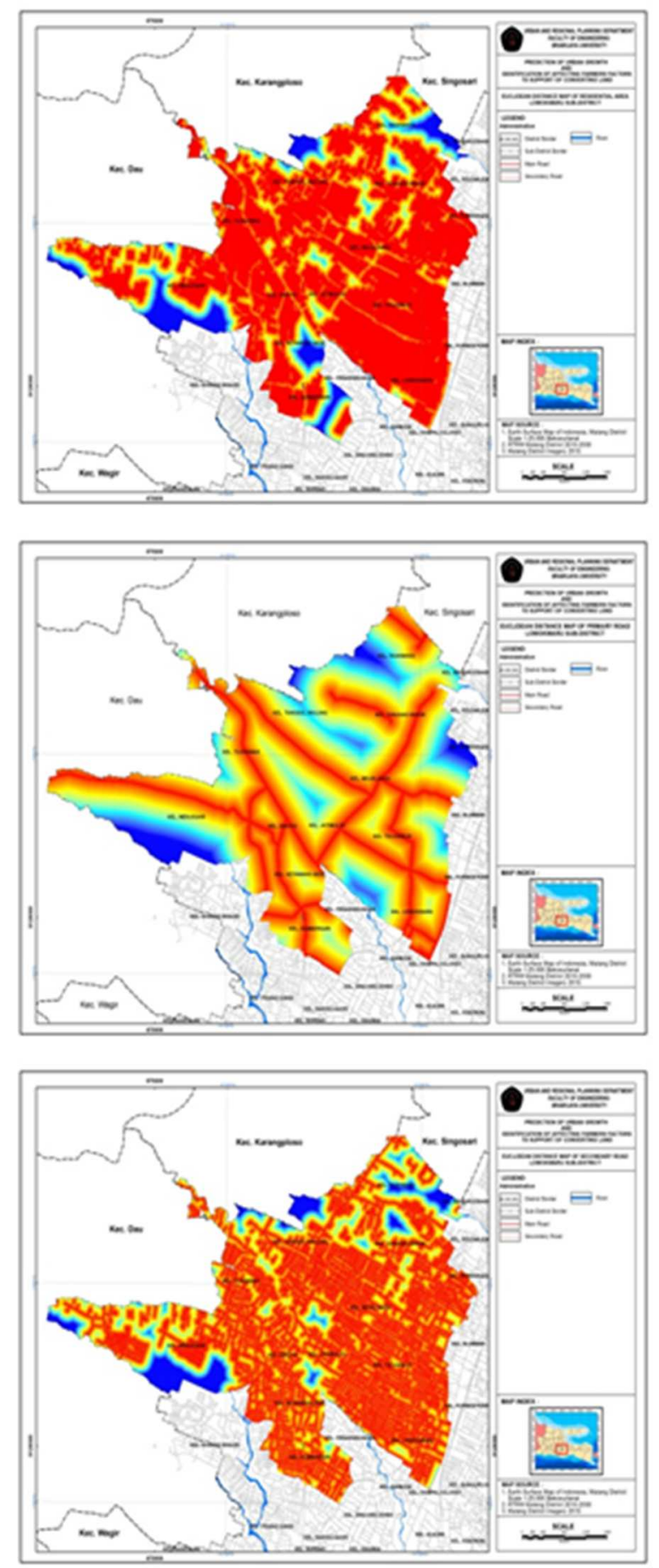

Figure 3. (Figure 3.a), the primary road (Figure 3.b), and the secondary road (Figure 3.c) 
Fuzzy Membership Analysis

Standardize each mapping distance of the driving factor using the linear method. Fuzzy membership sets monotonical decrease. At this stage, the distance value (Euclidean distance map) will be converted into real numbers, valued between 0 (farthest distance) and 1 (closest distance). This assessment is carried out by providing the best potential development value when approaching the driving variable.

In this analysis, several factor groups influencing the accession of settlement land development are (1) proximity to the existing settlement land; (2) proximity to the primary road; and (3) proximity to secondary roads. Linear method of fuzzy set membership monotonical decrease is applied to change the Euclidean distance value of all variables in the factor group. The results of the linear analysis of the method of fuzzy membership set monotonical decrease can be seen in Figures 4.a, 4.b, 4.c and 4.d.
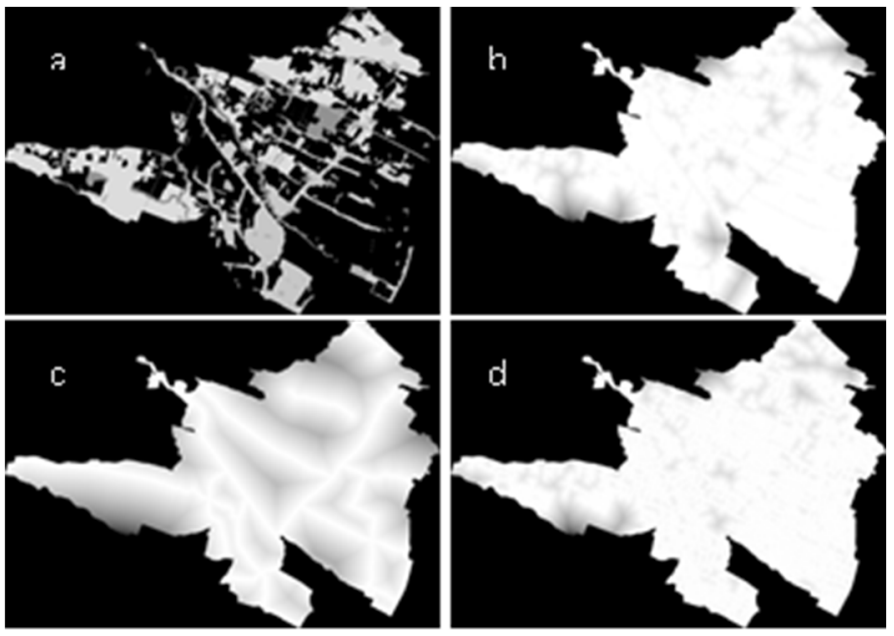

Figure 4. Fuzzy Set Membership Land Use in Lowokwaru District (a), Settlement area (b), Primary Road (c), Secondary Road (d) Year 2015

\section{Prediction of Settlement and Land Change}

The land change prediction inserts the map that has been made in the previous stage. Parameters in this stage include but are not limited to; projections, initial land use maps, transition map rules, neighborhood filters, and CA-Time Step. The base year of this study is 2015, while the land growth prediction is set in the year 2015. Thus the CA-Time Step used is 20 years with iterations per year. Next is filtering the neighborhood using a low pass filter. The low pass in question is that land growth has the same value and facilitates data ensuring no edge or boundary in this case. The results of the prediction of the growth of settlements per 5 years in Lowokwaru District can be seen in Figure 5.a to 5.d 

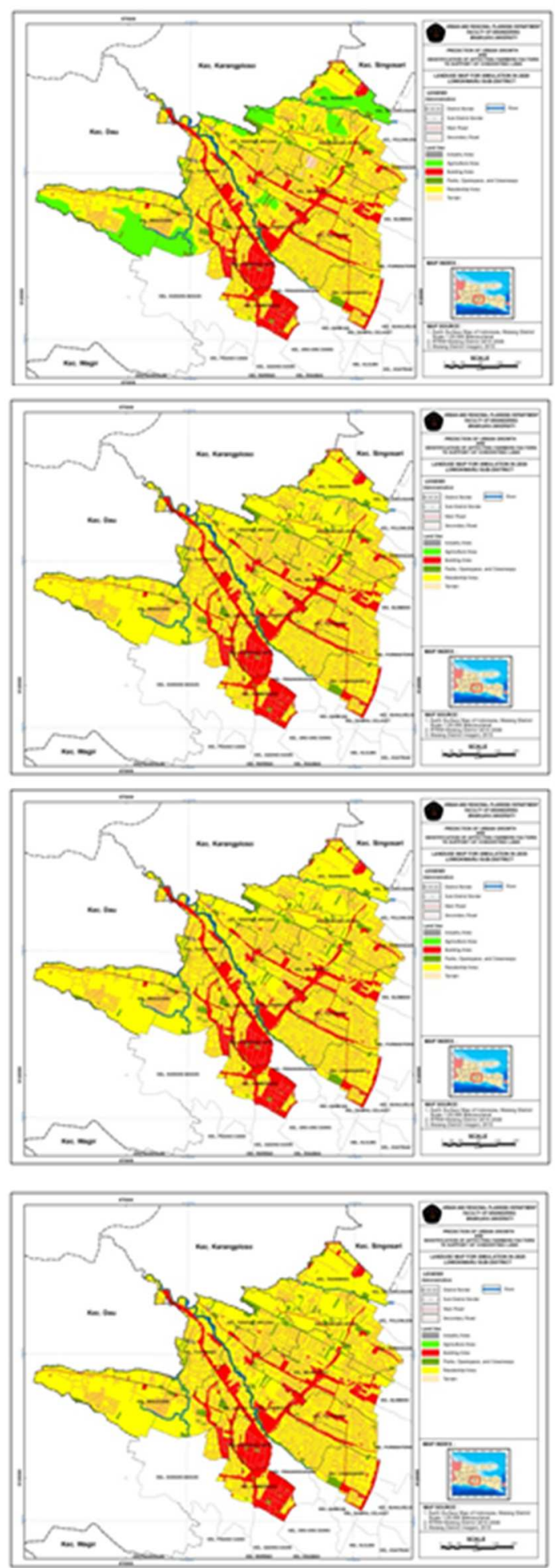
Figure 5. Prediction Map of Settlement Growth in 2020 (a), 2025 (b), 2030 (c), 2035 (d)

The Prediction map per five years above shows the growth of the settlement land. Settlement land growth is predicted to occur with the same visualization from 2025 to 2035 . This is due to projected simulated settlement land over the available land in Lowokwaru District. Land that can change its function to settlements as explained in determining the set transition rules, namely the use of agricultural land and use of vacant land. The projected settlement area in 2035 is 1,433.62 hectares, while the land available for land conversion is the sum of the agricultural land use and vacant land which is 682.15 hectares. The land availability significantly decreases land reduction, regarding the settlement, the land demand is higher than the supply for settlement land. The extent of land use change and simulation of land use change can be seen in Table 7 and Figure 6.

Table 6. Changes in land use per year

\begin{tabular}{|l|c|c|c|c|c|}
\hline \multirow{2}{*}{ Land Used } & \multicolumn{5}{|c|}{ 'Land Use Change Each Years (Ha) } \\
\cline { 2 - 6 } & $\mathbf{2 0 1 5}$ & $\mathbf{2 0 1 6}$ & $\mathbf{2 0 1 7}$ & $\mathbf{2 0 1 8}$ & $\mathbf{2 0 1 9}$ \\
\hline Industry & 1.75 & 1.75 & 1.75 & 1.75 & 1.75 \\
\hline Agriculture & 519.07 & 460.3 & 403.1 & 343.73 & 286.15 \\
\hline Build Land & 332.53 & 332.53 & 332.53 & 332.53 & 332.53 \\
\hline Open Space & 142.29 & 142.29 & 142.29 & 142.29 & 142.29 \\
\hline Empty Land & 76.16 & 63.25 & 48.77 & 36.46 & 22.36 \\
\hline Water & 28.99 & 28.99 & 28.99 & 28.99 & 28.99 \\
\hline Settlement & 1203.05 & 1274.73 & 1346.41 & 1418.09 & 1489.77 \\
\hline
\end{tabular}

\begin{tabular}{|l|c|c|c|c|c|}
\hline \multirow{2}{*}{ Land Used } & \multicolumn{5}{|c|}{ Land Use Change Each Years (Ha) } \\
\cline { 2 - 6 } & $\mathbf{2 0 2 0}$ & $\mathbf{2 0 2 1}$ & $\mathbf{2 0 2 2}$ & $\mathbf{2 0 2 3}$ & $\mathbf{2 0 2 4}$ \\
\hline Industry & 1.75 & 1.75 & 1.75 & 1.75 & 1.75 \\
\hline Agriculture & 229.06 & 164.72 & 93.47 & 21.79 & 0.01 \\
\hline Build Land & 332.53 & 332.53 & 332.53 & 332.53 & 332.53 \\
\hline Open Space & 142.29 & 142.29 & 142.29 & 142.29 & 142.29 \\
\hline Empty Land & 7.77 & 0.43 & 0 & 0 & 0 \\
\hline Water & 28.99 & 28.99 & 28.99 & 28.99 & 28.99 \\
\hline Settlement & 1561.45 & 1633.13 & 1704.81 & 1776.49 & 1798.27 \\
\hline
\end{tabular}

Table 7 shows the total number of land use changes up to 2024. Agricultural land will be exhausted by 2024 (even before 2035). Industrial built-up land, green open space, and waters are assumed to be fixed because this is fixed and we do not project it. Whereas vacant land will change to zero in 2022, or only eight years after the projection is carried out. Based on this analysis, an analysis can be carried out on a map where land use change is more visible from 2015 to 2024 (figure 6). We can see that the open space in 2015 runs out in 2024. This prediction can be used as inputs for the local government in preparing policies for the development of settlement areas in Malang City, especially in the Lowokwaru District. 

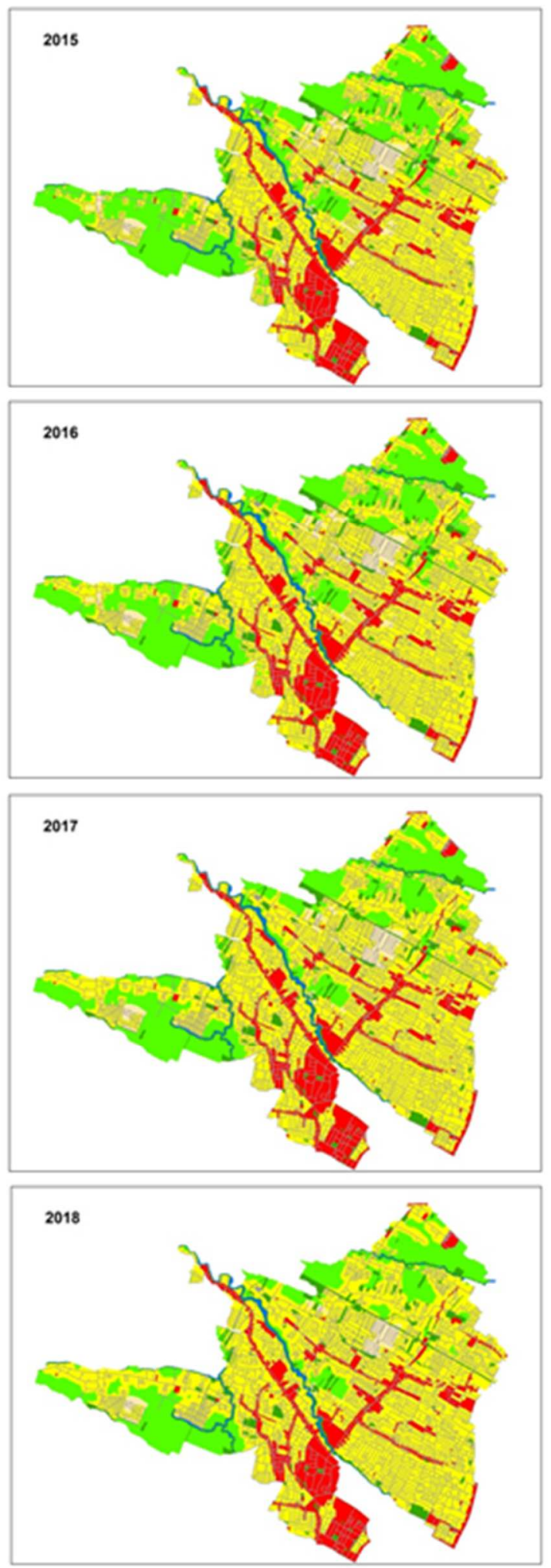

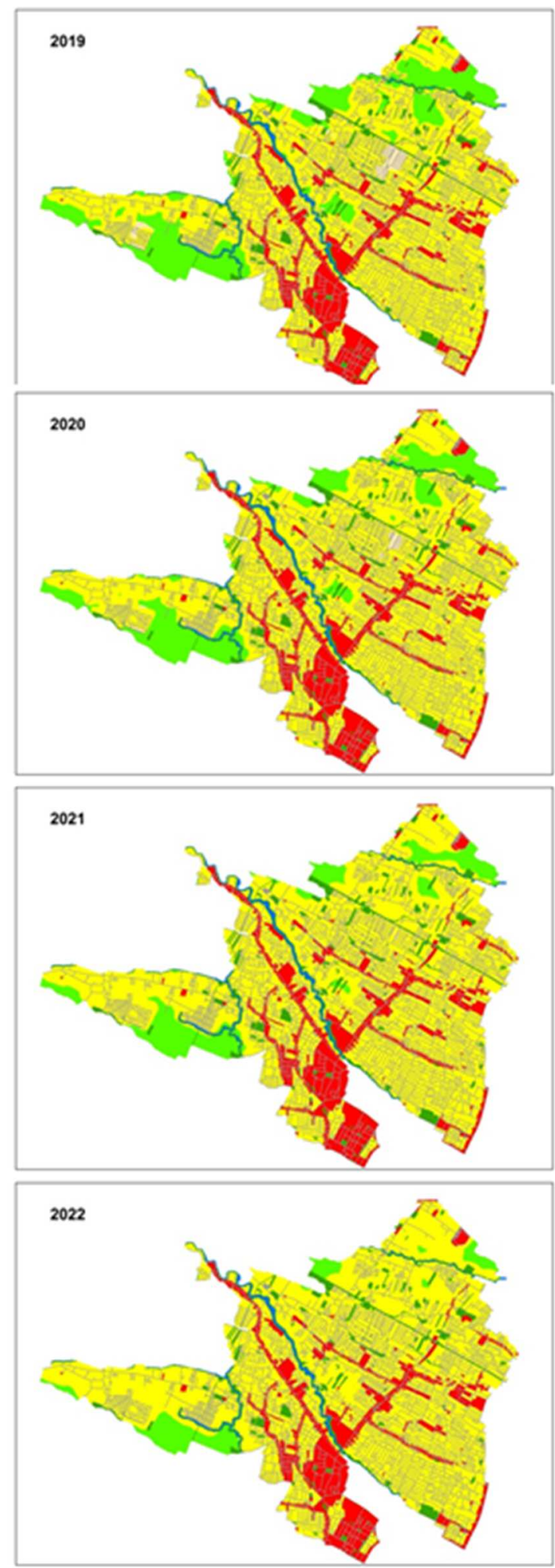

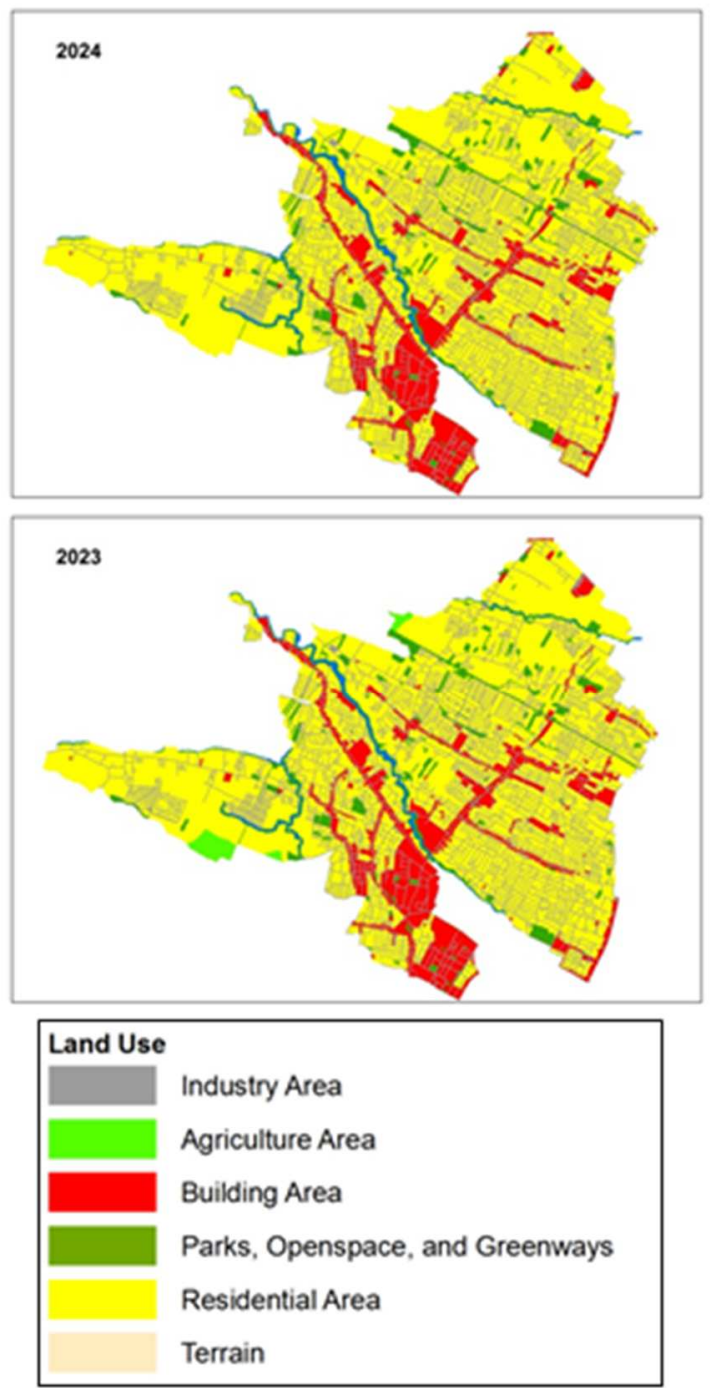

Figure 6. Prediction of Land use Change in Lowokwaru District

\section{Conclusion}

Settlement growth projections for 20 years from 2015 to 2035 requires a land area of $1,433.62$ hectares. In the simulation of regional settlement growth, the land conversion from agricultural use to settlement is evident in Merjosari Sub-district, Tasikmadu Sub-district, and Tunggulwulung Sub-district, while in some areas Mojolangu Sub-district, Jatimulyo Subdistrict and Tunjungsekar Sub-district, a small portion of the area is converted at the same stage. 
The settlement growth simulation shows that the need for settlement land cannot be fulfilled until 2035, the simulation shows that by 2024, the available agricultural land for settlements has been exhausted. As for the vacant land, it will be exhausted in 2022. The simulation of Sub-District settlement growth shows Sub-Districts with the slowest growth, namely Merjosari Sub-District and Tasikmadu Sub-District, this shows that the current availability of agricultural land in the two Sub-Districts is higher than other Sub-Districts in Lowokwaru District.

\section{References}

[1] Yunus, Hadi Sabari. Permasalahan Daerah Urban Fringe dan Alternatif (Urban Fringe and Alternative Regional Problems). Yogyakarta: Fakultas Geografi Universitas Gajah Mada, 1987.

[2] Brotosunaryo, V. D., "Pengaruh Perkembangan Aktivitas Ekonomi Terhadap Struktur Ruang Kota Di SWP III Kabupaten Gresik (The Influence of the Development of Economic Activity on the Urban Space Structure in SWP III Gresik Regency)". Jurnal Teknik PWK, Volume 1 Nomor 1. 2012

[3] Dinaryanti, N. Factors Affecting the Transfer of Agricultural Land Functions in Areas Through Irrigation of Colo Dam Sukoharjo Regency. 2014

[4] Turner, J. F. C. "Housing patterns, settlement patterns, and urban development in modernizing countries". Journal of the American Planning Association, vol. 34 (6), pp. 354-63. 1968.

[5] Prayitno G., and Sasongko W. "The Provision of Houses or Shelters for Migrant Workers on Urban Social Stability (Case Study of Settlement Area in Malang City Core)". Journal of Applied Sciences Research, vol. 7(6), pp. 853-859, 2011

[6] Irawan, B. dan S. Friyatno. "Dampak Konversi Lahan Sawah di Jawa terhadap Produksi Beras dan Kebijakan Pengendaliannya (The Impact of Rice Field Conversion in Java Rice Production and Control Policy)”. Jurnal Sosial-Ekonomi Pertanian dan Agribisnis SOCA, Vol.2 No.2, pp. 79-95. Fakultas Pertanian Universitas Udayana, Denpasar. 2002

[7] Statistical Center Bureau (BPS), Population Census, 2010

[8] Malang City in Figures, 2016.

[9] BPS (Statistical Center Bureau) Kota Malang, 2013. Hasil Sensus Pertanian (Agricultural Census) 2013. Malang.

[10] Hasyim A.W., Urban Climate: Poor Land Use Management As A Factor on Urban Heat Island (UHI) a Case of Klojen Sub District in Malang City, 2008

[11] Torrens, P., 'How cellular models of urban systems work (Part 1: Theory)'. Working Papers series, Paper 28, UCL Center for Advances spatial analysis, http://eprints.ucl.ac.uk/1371/1/paper28.pdf. 2000

[12] Manson, St.M, Sun, Sh. And Bonsal,. D., "Chapter 7: Agent-Based Modelling and Complexity”, In: Heppenstall, A.J., Crooks, A.T., See, L.M., Batty, M.,(eds), (2012), “Agent- based models of geographical systems". Springer, New York, pp 125-139, 2012

[13] Batty, M., Xie, Y. Urban growth using cellular automata models, in: D.J. Maguire, Batty, M. and Goodchild M, F. (eds.) (Ed) GIS, Spatial Analysis and Modelling (Redlands, ESRI Press). 2005a

[14] Menard, A. and Marceau, D.J. "Simulating the impact of forest management scenarios in an agricultural landscape of southern Quebec, Canada, using a geographic cellular automata", Landscape and Urban Planning, 79(3-4), pp. 253-265, 2007

[15] Karafyllidis, I. and Thanailakis, A., "A model for predicting forest fire spreading using cellular automata, Ecological Modelling”, vol. 99, pp. 8797, 1997

[16] Smith, T.S. and Stevens, G.T. "Emergence, Self-Organization, and Social Interaction: ArousalDependent Structure in Social Systems", Sociological Theory, vol. 14(2), pp. 131-153, 1996

[17] Liu Y. Modeling Urban Development with Geographic Information Systems and Cellular Automata. CRC Press, 2009 
[18] Samat N., Integrating GIS and CA-Markov model in evaluating urban spatial growth. 2009

[19] Hamid, Kiavarz Moghaddam, etc. Land Use Change Modeling in Tehran Using Geo Cellular Automata. 2009

[20] Chalkidou S., and Arvanitis A. "Building a Cellular Automata Model for Land-Use Change Simulation using Cadastral Data - A Case Study in Northern Greece (7476)", FIG Working Week 2015, 2015.

[21] DPKP Kota Malang.. Rencana Pengembangan Perumahan dan Kawasan Permukiman (Housing and Settlement Development Plans) (RP3KP) Malang City. Indonesia, 2013

[22] Regulation, the Minister of Public Housing, the Republic of Indonesia Number 10 year 2012 concerning the Organization of Housing and Settlement Areas with Balanced Residential. Jakarta

[23] Dinaryanti, Novita., Factors Affecting the Transfer of Agricultural Land Functions in Areas Through Irrigation of Colo Dam Sukoharjo Regency. 2014 